\title{
NOTAS SOBRE A LIBERDADE DA VONTADE EM AGOSTINHO E ANSELMO
}

\author{
Notes on Free-Will in Augustine and Anselm
}

Paulo Martines ${ }^{1}$

\begin{abstract}
RESUMO: A noção de que a vontade é um bem dado à criatura racional está presente tanto na reflexão de Agostinho como naquela de Anselmo, quando ambos abordam o tema do livrearbítrio. No entanto, a forma de considerar a vontade difere em cada um deles: para Anselmo, a liberdade será pensada como a reta determinação da vontade para o bem, é o poder de não pecar, expressão da retidão da vontade; já para Agostinho, a vontade livre será pensada como um bem intermediário, que pode aderir ao bem supremo ou afastar-se dele e converter-se para um bem que lhe é próprio, exterior ou inferior. O objetivo deste artigo é apresentar algumas notas de leitura sobre (1) a liberdade da vontade em Agostinho e (2) sobre a definição de liberdade em Anselmo.
\end{abstract}

PALAVRAS-CHAVE: Vontade; Liberdade; Livre-arbítrio; Ética; Mal.

ABSTRACT: The notion that the will is a good given to the rational creature is present in Augustine's as well as in Anselm's reflection when both approach the subject of free will. However, they differ on how to consider the will: for Anselm, freedom is thought of as the right determination of the will for good, it is the Power of not sinning, expression of the straightness of the will; for Augustine, free Will is understood as an intermediary good, which can adhere to the supreme good or withdraw from it and convert to a good that is its own, external or inferior. The aim of this article is to present some reading notes on (1) the freedom of the will in Augustine and (2) on the definition of freedom in Anselm.

KEYWORDS: Will; Liberty; Free-will; Ethics; Evil.

Ao leitor de Anselmo de Cantuária não é difícil constatar a proximidade do pensamento deste monge beneditino com aquele de Agostinho de Hipona, fato muitas vezes indicado pelo próprio Anselmo, como por exemplo, no prefácio do Monologion, onde diz não encontrar nada que esteja em dissonância com a autoridade de Agostinho. O fato se justifica uma vez que o Monologion despertou grande interesse por considerar

\footnotetext{
1 Doutor em filosofia pela Universidade Estadual de Campinas (UNICAMP), leciona filosofia na Universidade Estadual de Maringá (UEM). E-mail: martinespr@uol.com.br
} 
temas relacionados com a essência divina, segundo o encadeamento rigoroso de raciocínios (sola ratione), estando ausente o apoio da autoridade divina. Na carta a Lanfranco, para quem essa atitude gerou muitas suspeitas, Anselmo diz não apresentar nenhuma novidade em seu escrito, já que nada mais fez do que explicar de modo breve aquilo que Agostinho fizera de forma prolongada no De Trinitate ${ }^{2}$. A partir dessa indicação, cabe perguntar se essa fidelidade a Agostinho expressa no Monologion não poderia ser pensada a respeito do tema da liberdade, isto é, se a formulação anselmiana do diálogo De libertate arbitrii não seria devedora do diálogo De libero arbítrio de santo Agostinho? O título da obra de Anselmo como hoje conhecemos foi definido somente com a edição crítica de Schmitt (1960), pois antes recebia o mesmo título do diálogo de Agostinho. Neste artigo não farei um estudo exaustivo das obras em questão, mas pretendo apresentar tão somente algumas notas de leitura sobre (1) a liberdade da vontade presente no diálogo O livre-arbitrio de Agostinho; e (2) a formulação da liberdade para Anselmo como a determinação para o bem, presente no diálogo A liberdade de arbítrio. Partirei do seguinte pressuposto metodológico para a leitura dos diálogos em questão: Anselmo mobiliza toda sua capacidade dialética para encontrar uma definição de liberdade que seja idêntica para Deus, os anjos e o homem, e na qual estaria presente o traço distintivo do 'poder de não pecar', expressão da retidão da vontade; Agostinho, por sua vez, concebe seu diálogo para enfrentar desde as primeiras linhas a discussão sobre a origem do mal e da defesa da liberdade humana, investigada na esfera da vontade humana. Em sua luta contra o maniqueísmo, surge em primeiro plano a questão da natureza humana, e mais especificamente da relação alma e corpo. Para Anselmo, o pecado aparece como um problema a ser resolvido, na estrutura do diálogo, apenas posteriormente.

\section{Agostinho: a liberdade da vontade}

O De libero arbitrio de Agostinho contém três livros escritos em épocas diferentes, num intervalo de tempo de aproximadamente sete anos. O livro I e parte do II foram escritos por volta de 387, em Roma, durante sua segunda permanência na cidade, e o término do livro, já na África, ocorreu por volta de 393, após sua ordenação sacerdotal ${ }^{3}$.

\footnotetext{
${ }^{2}$ As referências do texto anselmiano são as seguintes: prefácio do Monologion e carta a Lanfranco (n. 77), presentes na edição L'oeuvre de S. Anselme de Cantorbery (vol. I). Paris: Cerf, 1986.

${ }^{3}$ Franco de Capitani diz que a conclusão da obra deve ser estendida até os anos de 395-6, período próximo de sua ordenação como bispo. Cf. Il 'de libero arbitrio' de Agostino. Studio introduttivo, testo, traduzione e commento. Milano: Vita e pensiero, 1994, p.24.
} 
Trata-se de uma obra marcada por uma preocupação anti-maniqueia e seu tema referese à origem do mal, excetuado aqui o papel da graça e da possibilidade de retorno ao estado primitivo ${ }^{4}$. A perplexidade diante do mal é indicada logo no início do diálogo:

A questão que me atormentou muito quando eu era jovem, e que, cansado, me impeliu para os hereges e neles me fez cair. Atormentei-me com esta queda, e a tal ponto fui esmagado por tamanho acervo de fábulas vãs, que, se aquele meu amor de encontrar a verdade não tivesse reclamado o favor divino, não poderia ter emergido de lá, recobrando alento precisamente na primeira das liberdades, a de investigar (I, 2,4) .

Essa breve indicação sobre o mal reflete a grande dificuldade desse tema, um verdadeiro "desafio à filosofia e à teologia". A dificuldade pode ser entrevista ao longo da tradição filosófica do ocidente, seja nas tentativas de superar (a aparente) contradição entre um Deus onipotente com o mal existente, seja na reação às explicações metafísicas que põem ao abrigo Deus e seus direitos ${ }^{6}$. Os argumentos do De libero arbitrio ao longo de seus três livros são mobilizados para a confirmação da bondade do criador, podendo cada um deles ser assim dividido: I) o homem é responsável pelo mal moral; II) Deus é o ser supremo, criador de todos os bens; III) Ele é digno de louvor por toda a sua obra ${ }^{7}$. É na discussão sobre o mal que se enraíza a formulação da noção de liberdade da vontade humana para Agostinho.

O livro inicia-se com a pergunta que repercutirá, de certo modo, na seqüência da reflexão de Agostinho: Deus é o autor do mal? A resposta negativa a essa indagação deslocará para a vontade a origem do mal, solução que só virá ao final do livro I: "Fazemos o mal a partir do livre-arbítrio da vontade" (I,16,35). Para Agostinho a

\footnotetext{
${ }^{4}$ É nas Confissões que se pode ter uma idéia mais precisa sobre o maniqueísmo e o problema do mal. No itinerário intelectual de Agostinho, sua adesão ao maniqueísmo implicava na busca de respostas relativas a Deus e ao homem, que muito rapidamente se manifestarão ao seu espírito como reais perplexidades, como se vê nessa passagem: "mas quem me criou? Não foi o meu Deus, que não somente é bom, mas ele é a própria bondade? Como explicar que a minha vontade tende para o mal e não para o bem? Será isso uma punição justa" Conf., VII,3. O maniqueísmo sinalizava a tese de que o mal não provém de Deus, mas de um princípio mal, o que de modo subliminar indicava um princípio concorrente ao divino O maniqueísmo exigia uma superação.

${ }^{5}$ Agostinho, Diálogo sobre o livre-arbitrio. Trad. Paula Oliveira e Silva. Lisboa: Imprensa Nacional Casa da Moeda, 2001. Os números aqui indicados correspondem respectivamente.ao livro, capítulo e parágrafo do texto agostiniano.

${ }^{6}$ Cf. P. Ricoeur, O mal . Um desafio à filosofia e à teologia. Campinas: Papirus, 1988. A primeira parte dessa dificuldade expressa a inconsistência de se afirmar ao mesmo tempo a onipotência de Deus e a existência do mal. A origem desse problema, no domínio da filosofia, pode ser atribuída a Platão, como nessa passagem de A República: "O deus já que é bom, não seria responsável por tudo, como muitos dizem, mas por poucas coisas em relação aos homens e por muitas não ... É que temos menos bens que males e não devemos ter nenhum outro como causa; e quanto aos males, devemos procurar outras causas, mas não o deus"(379 c). Platão, A República. Trad. Anna Lia Amaral de Almeida Prado. SP: Martins, 2006.

${ }^{7}$ Sigo a divisão temática sugerida por Sophie Dupuy-Trudelle, na notice (p.1291-1305) da edição francesa Le libre arbitre, publicada pela editora Gallimard: Saint Augustin, Les Cofessions. Dialogues philosophiques. Oeuvres I. Paris, 1998.
} 
dificuldade não é pequena, pois se pela fé reconhecemos de forma indubitável que tudo o que existe provém de Deus, e que ele não é o autor dos pecados, resta saber pela razão qual a origem do mal, movimento esse próprio da inteligência da fé. A investigação sobre a origem do mal conduz de modo específico à questão da responsabilidade humana. Interessa-nos aqui saber como Agostinho elaborou e desenvolveu seus argumentos a favor da livre escolha da vontade humana. À questão unde malum faciamus, a qual interpela pela origem do mal, precede um exame detalhado sobre a constituição das ações más. É o que Agostinho adverte a Evódio: "procuras, certamente, a origem do mal, antes de mais devemos examinar, o que é fazer o mal" $(I, 3,6)$. A resposta exige uma clarificação a respeito da autonomia da vontade, da natureza do ato livre.

Para o estudo das ações más (malefacta), o recurso empregado por Agostinho será aquele de mostrar a impossibilidade de entendê-las como provenientes da inteligência humana, da aprendizagem ou mesmo da autoridade da lei. Antes de tudo, não há uma ciência do mal, no sentido de que algo possa ser ensinado a esse respeito, de modo que o mal venha da razão. $\mathrm{O}$ mal não reside nem na autoridade do mestre, nem diz respeito à aprendizagem, pois se assim fosse ele residiria na inteligência do agente: "é evidente que de nenhum modo os males podem ser ensinados, dado que a aprendizagem é um bem". (...). "Portanto os males não se ensinam, e é em vão que procuras aquele por quem aprendemos a fazer o mal" $(I, 1,2)$.

De grande relevância para a discussão das ações más está a discussão de Agostinho sobre o adultério e o homicídio. A malícia do adultério não se consubstancia enquanto ação má porque se trata de um ato censurado que a lei proíbe, mas pela perversão da intencionalidade desse ato: "não é um mal porque a lei proíbe, mas a lei proíbe porque é um mal" (I,3,6). Há algo nas ações humanas que pode afetá-las de modo direto: a paixão (libido) e o desejo desenfreado (concupiscentia), termos relacionados entre si, ainda que não sejam idênticos. A paixão descreve a tendência para algum bem ou o desejo de evitar o mal, e o desejo desenfreado supõe certa perversão dessa intencionalidade. A paixão não é em si mesma a causa do mal. É a vontade desordenada que escolhe um bem inferior e se afasta daquilo que devia conservar. A malícia do homicídio revelará, por sua vez, toda a complexidade da questão. Há homicídios que lei não sanciona e outros que ela permite, como no caso do soldado que em combate mata o seu inimigo: "a lei não obriga a matar, mas apenas lhe outorga esse direito" (I,5,12). No entanto, há de se saber que entre os bens mundanos, mesmo aquele de preservar a vida, não pode ser tomado como um bem superior. 
Da consideração específica sobre o homicídio, a discussão de Agostinho revela a separação entre legalidade e justiça. Se as leis humanas são estabelecidas para preservar a paz entre os homens e a relação entre eles, as leis eternas são a expressão da justiça: "a lei eterna que está impressa em nós é aquela pela qual é justo que todas as coisas estejam absolutamente ordenadas" (I,6,15). Há de se ressaltar o traço contingente e mutável dos bens sujeitos às leis temporais, "realidades que temporariamente podemos chamar de nossas" $(\mathrm{I}, 15,32)$.

As coisas não são más em si mesmas, mas dependem do uso que fazemos delas; ao homem retamente ordenado a mente domina as realidades inferiores: "não seria absolutamente ordenado que as realidades mais fracas dominassem as mais fortes. Por isso julgo que a mente seja mais poderosa do que o desejo desenfreado, precisamente porque é reto e justo que ela domine" $(\mathrm{I}, 10,20)$. A vontade do homem tem um poder que lhe é próprio de tal modo que nada move a vontade para aquilo que ela não quer, senão ela própria. Entenda-se, nada de exterior ou superior, "nem Deus faz a mente racional ser escrava da paixão" (...) "Nenhuma outra realidade torna a mente companheira do desejo desenfreado, senão a própria vontade e o livre-arbítrio". (I,11,21). A questão, deste modo, é saber se a criatura racional não excederá a medida daquilo que lhe é próprio enquanto criatura, que conserve a sua ordem e não siga por um caminho que se apresente como afastamento de Deus ${ }^{8}$. No domínio próprio da cosmologia agostiniana, o homem tem a capacidade de perseguir ativamente e voluntariamente os fins fixados para ele por Deus. O problema é que ele pode não querer' ${ }^{9}$.

Do estudo e consideração sobre as ações más levadas a cabo nesse livro I, pode Agostinho dizer que elas nada mais são do que o afastamento das realidades divinas e a conversão às realidades temporais. A passagem abaixo diz isso expressamente:

É assim como dizes. Estou de acordo que todos os pecados estão contidos nesse único gênero, acontecem quando alguém se separa das realidades divinas e verdadeiramente permanentes, e se converte às realidades mutáveis e incertas. Ainda que estas tenham sido colocadas retamente na sua ordem e realizem a sua beleza própria, contudo, submeter-se-lhes, seguindo-as, é próprio de um espírito

\footnotetext{
${ }^{8}$ Cf. Agostinho, De ordine: "De fato, a alma dirige-se gradualmente para os costumes e para uma vida excelente, já não só pela fé mas pela firme razão. Àquele que observar atentamente a força e a potência dos números, parecer-lhe-á extremamente indigno e enormemente deplorável que, graças à sua ciência, o verso tenha uma boa métrica a cítara ressoe com harmonia, e que a sua vida em si mesma, que é alma, prossiga por um caminho desviado e, dominando nela o prazer, emita sons que lhe são dissonantes pelo estrépito absolutamente disforme dos vícios" (II, 19,50). Agostinho, Diálogo sobre a ordem. Tradução, introdução e notas de Paula Oliveira e Silva. Lisboa: Imprensa Nacional, 2000. Sobre essa passagem cf. E. Gilson, Introduction à l'étude de saint Augustin. Paris: Vrin, 1987, p.171.

${ }^{9}$ No plano da moralidade dos nossos atos, deve-se frisar a investigação de Agostinho que aparece nas Confissões (VIII,10), especialmente no embate entre o desejo de Deus e a vontade de viver segundo o homem; ou ainda, na Cidade de Deus (XIV,28), onde dois amores (= duas vontades) distinguem a cidade celeste da cidade terrestre.
} 
perverso e desordenado que, por ordem e direito divino, foi colocado, antes de mais num lugar superior, para as conduzir, a um sinal seu. E assim também que já se vê de um modo perfeito e evidente que, depois desta questão, acerca do que é fazer mal se siga a investigação daquilo que estabelecemos, isto é, de onde vem que façamos o mal. Com efeito, se não estou em erro, as razões apresentadas mostraram que fazemos o mal a partir do livre-arbítrio da vontade (I,16,35).

Ao reconhecer que o mal tem sua raiz no livre arbítrio da vontade, as dificuldades não se desvanecem, ao contrário, persistem: como admitir que um Deus bom e onipotente dotasse o homem com um poder, do qual seu exercício conduz ao pecado. Pergunta Evódio: "quero saber se era necessário que o próprio livre-arbítrio, pelo qual já nos convencemos que temos a faculdade de pecar, nos fosse dado por aquele que nos criou" $(\mathrm{I}, 16,35)$. Por que o livre-arbítrio foi dado ao homem se com ele podemos fazer o mal? Deus não seria assim o autor das nossas más ações? Essas questões mobilizam o livro II do Livre-arbitrio, do qual o primeiro movimento é o reconhecimento de que Deus é tal como reconhecemos pela nossa fé (o ser em relação ao qual nada é superior) ${ }^{10}$, de modo que de forma indubitável dele provêm todos os bens, sendo a mesma vontade um bem, designada como bem médio, que adere ao bem supremo ou afasta-se e converte-se a um bem próprio, exterior ou inferior ${ }^{11}$. O movimento da vontade que gera o mal nada mais é do que a renúncia de se dirigir ao criador, é uma perversão da vontade. Assim, a conclusão deste livro II assevera que a origem do mal é boa, o livre-arbítrio, caracterizado pela possibilidade de escolha. Mas, qual a origem desse movimento de afastamento do bem imutável? Tal movimento de aversão nada mais é do que um movimento de defecção; a origem do mal é a tendência ao nada, mais precisamente ausência de realidade.

A reflexão sobre o mal moral comporta uma dificuldade que recai diretamente sobre a própria vontade. Se as ações humanas não são o que devem ser, na medida em que não expressam a retidão da criatura, no entanto, a decisão da vontade é tomada livremente, e é como livre que ela escolhe o mal. A resposta ao considerar que a vontade em si mesma é um bem, recobre a idéia fundamental da identidade da vontade consigo, vontade

\footnotetext{
${ }^{10} \mathrm{Cf}$ Agostinho, DLA II,6,14. O conhecido argumento de Anselmo, dito argumento ontológico, para provar a existência de Deus, é expresso numa fórmula semelhante: 'algo tal que se não pode pensar nada maior' (Proslogion, cap.2). Grande parte desse livro II de Agostinho (c.2 ,5-15,39) é mobilizado para 'provar a existência de Deus', que deve ser corretamente entendida: "la dimostrazione dell'esistencia di Dio non há senso in se stessa ma soltanto perché è um presupposto al concetto di providenza che vienne svolto nella seconda meta del libro. Il concetto di provvidenza é indispensabile a um discorso sensato sul libero arbítrio". D. Gentili, Introduzione, Il libero arbitrio. Sant'Agostino. Dialoghi. III, 2. Roma: Citt'a Nova editrice, 1992, p.140.

${ }^{11}$ Daqui seguem os três tipos de homens correspondentes à inclinação de sua vontade: 1) aquele que quer seu próprio poder, o soberbo; 2) aquele que quer bens alheios, o curioso; 3 ) aquele que quer o prazer do corpo, o lascivo.
} 
necessariamente livre: “do mesmo modo que é através da razão que conhecemos todas as coisas que dizem respeito à ciência e, contudo, a própria razão se deve contar entre as realidades que conhecemos pela razão", também "é através da vontade livre que fazemos uso de tudo o mais, não te deves admirar que também seja pela própria vontade livre que dela possamos fazer uso".(II,19,51). A ênfase nesse poder do querer isenta Deus de todo pecado, como também qualquer outra natureza: é a vontade que dispõe dela mesma e, em si mesma, não é um mal. O homem é chamado por Deus a viver segundo certa ordem e é capaz de ser refratário ou dócil a este chamado ${ }^{12}$.

Mas o diálogo sobre o livre-arbítrio aprofunda o tema da natureza da liberdade da vontade ao investigar no livro III, logo em seu início, se a origem do movimento da vontade seria necessária. Evódio expõe o problema de modo direto: "se a vontade livre nos foi dada de tal modo que possui este movimento por natureza, então converte-se a esses bens necessariamente. E onde dominam a natureza e necessidade, não se pode identificar nenhuma culpa" (III,1,1). O que caracteriza o ato humano livre é que a volição pressupõe um ato de escolha, diferente dos seres naturais, que são orientados de modo determinado; uma pedra não escolhe cair, seu movimento é natural: "na verdade esse movimento difere daquele porque não está no poder da pedra travar o movimento que a lança para mais baixo" (idem).

Ainda que se admita a distinção entre natural e voluntário, é preciso harmonizar o livre-arbítrio da vontade com a presciência divina, o poder de Deus que conhece de antemão aquilo que ocorrerá ao homem. A presciência não seria uma forma de aproximar o voluntário do natural (necessário)? Se Deus tem a presciência de algo, é necessário que esse algo seja no futuro. Ora, a palavra necessidade parece invocar qualquer tipo de coação ou proibição, por exemplo, quando se afirma que algo coibiu ou forçou determinada vontade ou desejo de se manifestar. Parece, então, que o livre-arbítrio da vontade não concorda com a presciência de Deus, problema complexo (quaestio magna), que põe em suspenso a própria liberdade humana.

\footnotetext{
${ }^{12}$ A primeira liberdade (o livre-arbítrio) foi concedido para que a criatura racional adquirisse o mérito, diz Agostinho na Cidade de Deus. A liberdade dos eleitos, por sua vez, é uma incapacidade para pecar: "Nem os bem-aventurados serão privados de livre-arbítrio por não sentirem o atrativo do pecado. Pelo contrário, será mais livre esse arbítrio desde que se veja liberto do atrativo do pecado até chegar ao atrativo indeclinável de não pecar. Efetivamente, o primeiro livre-arbítrio dado ao homem quando ao princípio criado na retidão, poderia não pecar, mas também podia pecar; mas este último será tão poderoso que já não poderá pecar; mas isto também por dom de Deus e não devido ao poder de sua natureza. Efetivamente, uma coisa é ser Deus e outra coisa é ser participante de Deus. Deus por natureza não pode pecar, - mas o participante de Deus recebe dele o dom de não pecar". Agostinho, A Cidade Deus, XXII,30. Trad. J.Dias Pereira. Lisboa: Fundação Calouste Gulbenkian, 2008.
} 
As questões aqui presentes podem ser assim enunciadas: 1) como não seria necessário acontecer aquilo que se sabe de antemão; 2) por que seria justo a punição para aquele que age necessariamente; 3) por que não imputar a Deus aquilo que ocorre necessariamente. A dificuldade do problema parece levar à negação da presciência, para se salvar o livrearbítrio, ou negar este para afirmar a presciência divina.

De fato, temos uma falsa oposição entre presciência e livre-arbítrio: Deus conhece nossas ações futuras e isso não implica que queiramos algo sem ser voluntariamente. Deus sabe que as ações serão voluntárias. Por fim, quando queremos algo, não nos falta a vontade: "a nossa vontade não seria nossa, a não ser que estivesse em nosso poder, e é livre para nós. Mais precisamente, porque está em nosso poder, ela está livre para nós" (...) “Como Deus conhece de antemão a nossa vontade, existirá a própria vontade, que ele conhece de antemão" (III,3,8).

\section{Anselmo: a definição de liberdade}

A principal formulação sobre a liberdade da vontade em Anselmo de Cantuária aparece no diálogo $A$ liberdade de arbitrio, que compõe com outros dois diálogos, $A$ verdade e $A$ queda do diabo, uma trilogia sobre a liberdade. Seguirei de perto os argumentos presentes ao longo dos capítulos 1-4 do diálogo anselmiano, no qual as personagens são identificadas como discípulo (aquele que pergunta) e mestre (aquele que responde). ${ }^{13}$

O capítulo primeiro do De libertate arbitrii é considerado como programático para a economia da obra, principalmente na medida em que mostra, de forma clara e precisa, o objetivo de Anselmo, identificado tanto na busca de uma definição de liberdade como nos contornos determinados dessa procura. Em outras palavras, ele serve de introdução à obra propriamente dita.

A primeira parte dessa introdução é comandada pela pergunta do discípulo e a resposta do mestre. Tal pergunta que abre propriamente o diálogo, resume em poucas linhas o grande problema do livre-arbítrio, de um lado, e a presciência, predestinação e graça de Deus, do outro:

Já que o livre-arbítrio parece incompatível com a graça, a predestinação e a presciência de Deus, desejo saber o que é a liberdade de arbítrio e se sempre a possuímos. Com efeito, se a liberdade de arbítrio é o poder de pecar e não pecar, como dizem frequentemente alguns, e se sempre a temos, como necessitamos da graça? Se nem sempre a temos, porque nos é imputado o pecado, quando não pecamos sem o livre-arbítrio (207:4-10).

\footnotetext{
${ }^{13}$ Citarei Anselmo pela edição crítica de F.S.Schmitt. Opera omnia. Stuttgart: Bad Cannsttat, 1984, 2 vol.
} Os números arábicos entre parêntesis indicam a página e as linhas dessa edição. 
É indicado claramente o objetivo do De libertate arbitrii: a) trata-se de investigar o que é a liberdade ${ }^{14}$ e b) se sempre a possuímos. Veremos que o propósito de Anselmo será o de procurar uma definição de liberdade de arbítrio a partir da qual o arbítrio e a própria vontade sejam reconhecidos como livres ${ }^{15}$. O que definirá o tratamento da questão será a presença (ou não) de uma vontade reta, que não é outra coisa senão a justiça. A tarefa de Anselmo será a de considerar ao longo desse tratado a liberdade como algo que é inamissível na criatura racional, ainda que seja necessário fazer algumas distinções referentes à presença ou não da retidão. Se for admitida a definição de liberdade enquanto uma alternativa, chega-se a uma incompatibilidade entre a graça e o livre-arbítrio. Isso posto, surge o seguinte dilema: ou o homem tem a capacidade de decidir a alternativa e a graça não é mais indispensável para fazer o bem; ou o homem está privado de fazer o bem e a imputabilidade do pecado não tem cabimento.

Anselmo negará a possibilidade de se pensar a liberdade como uma alternativa entre o posse peccare e o posse non peccare. Se a liberdade fosse o poder da alternativa, ela seria negada a Deus e aos anjos bons, que não podem pecar, o que seria uma blasfêmia. A liberdade recebe, desde as primeiras linhas do tratado, uma distinção negativa expressa na sua condição de não pecar (uma potentia impeccandi), que determina igualmente a definição de liberdade de arbítrio (potestas servandi rectitudinem voluntatis propter ipsam rectitudinem). Desde o início, Anselmo tratará a liberdade enquanto uma potestas.

Mesmo sabendo das diferenças entre o livre-arbítrio de Deus e dos anjos, de um lado, e do homem, de outro, Anselmo deseja encontrar uma definição ${ }^{16}$ segundo o nome que tenha validade para todos (definitio secundum nomen ...omnium ... est eadem). O que

\footnotetext{
${ }^{14} \mathrm{O}$ que é igualmente indicado no prefácio do De veritate (173:11) e confirmado no último opúsculo de Anselmo, o De concordia ( q. 1, cap. 6). Tal objetivo, como veremos, é o de procurar uma definição de liberdade.

${ }^{15}$ Naquilo que diz respeito ao vocabulário utilizado por Anselmo, encontramos tanto o emprego de libertas arbitrii como o de liberum arbitrium para definir esse poder que é o de conservar a retidão da vontade. É o que sugere a passagem presente no cap. 3. Após a definição de liberdade - "libertas arbitrii est potestas servandi rectitudinem voluntatis propter servandi rectitudinem" (212:19-20) —, encontramos a mesma definição ligeiramente modificada: "liberum arbitrium non est aliud quam arbitrium potens servare rectitudinem voluntatis propter ipsam rectitudinem"(id., 22:23).

${ }^{16}$ A mesma intenção já aparecera no De veritate, no qual Anselmo procurava uma definição de verdade. Nesse sentido, Evans fala de um "método definicional" em Anselmo (cf. Anselm and talking about God. Oxford: Clarendon Press,1978, p. 81) Tal afirmação ganha sentido se lembrarmos que a definição é um dos procedimentos-padrão da dialética elementar. É o que vemos, por exemplo, num retórico latino como Mário Vitorino, que no seu tratado De definitionibus, retomando Cícero, define assim o termo definição "Oratio quae id quod definit explicat quid sit (apud., Hadot, Pierre, Marius Victorinus. Recherches sur sa vie et ses oeuvres, p. 333). Em Agostinho, lemos: "Definitio nihil minus nihil amplius continet, quam id quod susceptum est explicandum; aliter omnino vitiosa est (De quantitate animae, xxv, 47).
} 
temos é o seguinte: Deus, os anjos e os homens são livres, isto é, estão sob uma mesma definição de liberdade; isso, entretanto, não implica que são igualmente livres. Isso é confirmado no último capítulo da obra, onde encontramos uma divisão da liberdade segundo a presença ou não da retidão da vontade.

Nessa primeira tentativa de considerar a possibilidade de encontrarmos uma definição de liberdade, somos levados a reconhecer o papel central que a vontade exercerá nesse processo. Não há dúvidas de que a vontade seja um bem que dignifica o homem perante as outras criaturas. Anselmo se valerá de um vocabulário muito particular para descrever os movimentos dessa vontade, que por vezes são contraditórios. Assim, a vontade mais livre é aquela que tem o que convém, o que é mais vantajoso e o que não pode ser abandonado, diferente daquela que tem esse mesmo bem e pode perdê-lo e ser assim conduzida àquilo que é nocivo e não conveniente. É por fim mais livre a vontade que não pode desviar-se de sua retidão de não pecar. Importante frisar que a palavra retidão, fundamental para a elaboração do pensamento ético de Anselmo, aparece associada à noção de vontade. $\mathrm{O}$ conceito de retidão recebe um tratamento adequado no diálogo $A$ verdade. Quando a mesma vontade volta-se para aquilo que lhe é inferior, torna-se menos livre. O poder de pecar afeta diretamente a vontade, mas ele não é nem a liberdade e nem parte da liberdade. No entanto, não se pode dizer que o poder de pecar seja um poder neutro.

Um primeiro movimento de fundamental importância é suprimir da liberdade qualquer tipo de necessidade. A dificuldade surge quando no contexto teológico for considerado o pecado (homem e anjo), pois ambos pecaram, e o poder de pecar não pertence à liberdade, como já foi visto mais acima. Então, poder-se-ia pensar que tal ato foi realizado por necessidade. Ainda sobre o fato do pecado: como pode ter sido feita livre a criatura, se o seu livre-arbítrio pôde ser dominado pelo pecado? A resposta de Anselmo é clara: "a natureza angélica e a nossa pecaram no início e puderam ser escravas do pecado" (209,2729). O desvio para aquilo que é nocivo e que não convém está diretamente ligado às noções que destacam a ideia de que uma escolha é livre e espontânea. E mais, esse ato não é identificado com a liberdade, visto que esta não se identifica com o livre-arbítrio:

Pecaram pelo seu arbítrio que era livre, mas não por aquilo de onde ele era livre, isto é, não pelo poder pelo qual poderiam não pecar e não ser escravos do pecado, mas pelo poder que tinham de pecar, que não favorecia a liberdade de não pecar nem coagia à servidão do pecado (210:6-9).

Essa citação acima mencionada revela-se importante para a economia da argumentação. A primeira parte da oração acima confirma o epíteto livre do ato; a 
segunda indica que o lugar de proveniência (o unde) desse ato não é aquele que é identificado com o poder de não pecar, próprio da liberdade, mas com o poder de pecar, que acompanha o livre-arbítrio. Vale ressaltar que Anselmo considera o livre-arbítrio dotado de uma espontaneidade, em oposição a toda coação ou necessidade e, nesse sentido, podemos falar que a escolha é livre. A liberdade, enquanto um poder de não pecar, será considerada em pormenores no cap. 3 do De libertate arbitrii. Convém salientar que essa distinção entre poder de pecar e poder de não pecar procura garantir uma concepção de liberdade que não se resume na simples capacidade volitiva de querer isso ou aquilo. É o que sugere uma passagem significativa do De concordia, última obra de Anselmo: "com efeito, não é a mesma coisa o arbítrio e a liberdade pela qual ele é dito livre. Em muitos casos falamos de liberdade e arbítrio, por exemplo, quando se diz que alguém tem a liberdade de falar ou de calar-se, e que está em seu arbítrio querer um ou outro" (256:1-4).

$\mathrm{O}$ aspecto mais importante presente nessas considerações preliminares - sobre o pecado do anjo e do homem - é aquele que diz respeito à espontaneidade do ato ele próprio (o sponte), o traço principal do livre-arbítrio, completamente oposto a necessitas. S.Vanni-Rovighi afirmou que o poder de pecar na reflexão de Anselmo ficou à sombra, não recebendo uma denominação clara, o que somente ocorrerá, segundo a autora, com S. Bernardo, na sua libertas a necessitate ${ }^{17}$. Não nos parece ser o caso aqui. O que Anselmo procura destacar é outra coisa: é o poder de não pecar que assume papel relevante na sua reflexão sobre a liberdade ao longo desse tratado e, nessa medida, é ele a expressão de uma vontade reta. Para Anselmo, é impossível que a inclinação para o mal se efetive segundo as mesmas condições pelas quais se pratica o bem ${ }^{18}$.

A definição procurada por Anselmo será apresentada no capítulo 3 do diálogo que estamos a considerar. Se não houve qualquer tipo de coação na prática do ato pecaminoso, reconhece-se que a vontade do homem (e do anjo) é livre. Mas como entender essa liberdade. Aceitar que a criatura a recebeu como um dom gratuito de Deus para afirmar a sua dignidade enquanto ser criado, é algo que pode muito bem ser recebido pela fé. Mas no movimento interno da discussão, trata-se de entender esse fato: “credo, sed desidero intelligere".

\footnotetext{
${ }^{17}$ Vanni-Rovighi, S. Ética in S. Anselmo, in Analecta Anselmiana. Untersungen uber Person und Werk Anselm von Canterbury. Vol. I. Frankfurt: Minerva, 1969, p.90

${ }^{18}$ Cf. Hopkins, J. A companion to the study of St. Anselm. Minneapolis: University of Minnesota Press, 1972, p.143.
} 
A liberdade não foi concedida ao homem - e a referência de Anselmo é pensar a situação ante peccatum - para o homem valer-se de sua vontade para fazer o que bem entender. Há uma finalidade intrínseca que orienta a destinação desta liberdade: "para que te parece que tiveram aquela liberdade de arbítrio?" (211:5) Eles tiveram a liberdade, diz o discípulo, "para querer aquilo que deveriam e seria mais vantajoso querer". A importância dessa fórmula é capital para o pensamento de Anselmo, já que ela é a própria definição da retidão da vontade presente no diálogo $A$ verdade: querer aquilo que se deve querer. A liberdade de arbítrio foi dada em vista da retidão da vontade. A isso deve ser acrescentado o motivo pelo qual (o propter quid) a criatura deveria conservar essa retidão: pela própria retidão e não por outra coisa.

Essa liberdade deve ser pensada a partir dos termos ad quid e propter quid (finalidade e motivo). Não se trata aqui de ressaltar aspectos de natureza gramatical. O que esses termos representam no interior do pensamento de Anselmo? Primeiro: a afirmação de que a liberdade da criatura racional deve possuir uma vontade determinada, na medida em que ela quer o que deve e o que é melhor; segundo, que tal vontade (reta) deve ser conservada por causa da própria retidão, pois a fé afirma que a liberdade é ordenada à justiça: "sed ad iustitiam prodesse arbitrii libertatem credimus" (212: 15). O propter ipsam denota o reconhecimento da magnificência desse bem que foi dado ao homem.

Uma vez definidos os elementos essenciais da liberdade de arbítrio: a) que toda liberdade é poder, b) dado por Deus à criatura racional c) para que seja conservada por ela mesma, Anselmo define a liberdade de arbítrio como o "poder de conservar a retidão da vontade pela própria retidão (212:20). O objetivo traçado no início do tratado, o de procurar uma definição de liberdade que não incorporasse o poder de pecar, está alcançado.

Anselmo estabelece uma definição "tão perfeita segundo o gênero e a diferença" (225:13), na qual o traço essencial é a idéia mesma de potestas. Na confirmação da liberdade enquanto um poder, temos a presença da eficácia de um querer: o de não se submeter (a algo que lhe é estranho, como a força da tentação) e o de conservar a retidão da vontade, que é exatamente o fato de se querer aquilo que se deve, que no caso da natureza criada será o de identificar o seu querer com o de Deus. Desse modo, pode-se falar muito justamente de submissão à vontade de Deus, da criatura em relação ao criador, pois ela não é a expressão da servidão. Acreditamos que as palavras iniciais desse diálogo vão nesse sentido: o poder de pecar não pertence à liberdade, e a vontade é mais livre quando quer e pode não pecar, a ponto de não se deixar desviar de sua reta resolução de 
não pecar. Fato em princípio paradoxal, pois teríamos de admitir uma liberdade que não pode realizar certas coisas. Mas, ao reconhecermos a livre resposta da criatura racional, estabelecida segundo uma vontade reta e como fruto do amor, a dificuldade é suprimida. Quando, por sua vez, a vontade se vê diminuída em sua eficácia, temos a situação de uma vontade que quer e não pode. Após o pecado, privada daquilo que lhe era essencial, a criatura só recupera o poder perdido pela graça.

E. Gilson assinala muito justamente que, com a consideração do conceito de potestas, Anselmo conseguiu discernir o sentido e o alcance da distinção velle/posse feita por Agostinho. Diz Gilson: "Saint Anselme est peut-être celui qui a le plus clairement discerné le sens et la portée de la question"19. Para Anselmo entre o querer e o poder há antes de tudo uma identidade essencial. Completa Gilson: “...puisque la volonté est essentiellement pouvoir, on ne saurait confondre le mauvais choix avec sa liberté. (...) Une liberté qui se diminue, même librement, est infidèle à son essence. C'est pourquoi, précisément parce que tout vouloir est un pouvoir, toute diminution du pouvoir de vouloir diminue la liberté du libre arbitre" ${ }^{20}$.

O momento do texto que se segue à definição da liberdade de arbítrio apresenta a idéia de que essa liberdade é inamissível e que ela está sempre presente. A preocupação do discípulo com a situação da liberdade após o pecado está novamente presente: uma vez abandonada a retidão da vontade, como conservar aquilo que já não temos? Em outros termos, como podemos ainda falar de liberdade? Repetindo um movimento já anotado acima, temos a confirmação da presença da liberdade na natureza racional: "Mesmo se falta a retidão da vontade, ainda assim a natureza racional não possui menos aquilo que lhe é próprio. Com efeito, não possuímos nenhum poder que seja suficiente por si só para passar ao ato" (212: 29-31) ${ }^{21}$.

$\mathrm{Na}$ ausência da retidão da vontade, a natureza racional não possui menos (minus habet), não deixa de ter aquilo que lhe pertence ${ }^{22}$. Ela (criatura) possui a liberdade, mas não pode "exercê-la"; na linguagem de Anselmo, não pode usá-la. Somente é possível entendermos esse novo passo se considerarmos a distinção entre os vários sentidos do termo poder. É exatamente sobre essa distinção que o segundo momento da resposta

\footnotetext{
${ }^{19}$ Gilson, E. L'esprit de la philosophie médiévale. 2 ed. Paris: Vrin, 1969, p.299.

${ }^{20}$ Gilson, E, ibidem.

${ }^{21} \mathrm{O}$ sentido de natura presente nessa passagem não se presta a equívocos: ela exprime o id quod est: uma natura humana, rationalis.

${ }^{22}$ Encontramos essa mesma idéia em Boécio, para quem nenhuma criatura racional pode ser privada da liberdade de arbítrio: "Est, inquit neque enim fuerit ulla rationalis natura, quin eidem libertas adsit arbitrii" (Philosophiae Consolatio, V,2).
} 
considera o problema da ordenação ao ato, afirmando que nenhum poder por si só é suficiente para passar ao ato. $\mathrm{O}$ exemplo da potestas videndi fornece uma boa explicação disso. Tal pessoa que tem a vista sã tem o poder e o instrumento para ver algo, por exemplo, uma montanha. Caso faltasse a luz, ou se alguém a impedisse de ver a montanha, essa pessoa não enxergaria, diria que não tem condição para vê-la. Se faltasse qualquer um destes quatro "poderes": o instrumento, a coisa, o meio que favorece ou o meio que desfavorece, certamente a visão estaria prejudicada. Pode-se concluir que alguém tem sempre esse poder, mesmo que não o use, por exemplo, pela falta da coisa ou do meio que permite vê-la. Para o caso da liberdade, uma coisa é o poder enquanto instrumento, sempre presente na criatura racional; e outra coisa, o poder enquanto uso, que depende da presença da retidão da vontade.

Para Anselmo, a retidão da vontade existe apenas na natureza racional, e nessa medida compete a ela, dotada de razão e vontade, entender e querer essa retidão. No entanto, o entender e o querer não são suficientes por si mesmos para se ter a retidão da vontade. É preciso ir além dessas faculdades. O cap. 12 do diálogo A liberdade de arbítrio repete a mesma idéia ligeiramente modificada: "quando a retidão da vontade nos faz falta, temos em nós a aptidão para entender e querer, pela qual podemos conservá-la por causa dela própria quando a temos" (224:14-16). A marca da conjunção temporal (cum) indica um traço característico dessa retidão da vontade: o ter a retidão é indispensável para querêla. Anselmo não investiga como os escolásticos do séc. XII - XIII, se o livre-arbítrio seria predominantemente expressão da vontade ou da razão, ou ainda, de ambos conjuntamente.

A tarefa realizada até o momento foi a de encontrar uma definição de liberdade e de afirmar sua presença na criatura racional. O trabalho dialético exige, por sua vez, a confirmação da definição encontrada a fim de verificar a sua excelência. As partes que a compõem são de tal forma que nada deve ser acrescentado ou retirado (225:15-27). Temse o seguinte: conservar (poder de conservar ...) a separa (separare) de todo outro poder que não é conservar, como quando falamos do poder de rir ou de marchar; com a retidão, acrescenta-se (addere) que se trata de conservar a retidão e não outra coisa; da vontade, é o acréscimo (additamentum) que especifica qual a retidão que deve ser conservada, não aquela que encontramos no pensamento ou nas coisas, mas sim a retidão da vontade; pela retidão ela mesma, a separa (dividere) do querer conservar a retidão da vontade por outra coisa qualquer. 
Desde o início o objetivo de Anselmo era encontrar uma mesma e única definição de liberdade; mas Deus, de um lado, e a criatura racional, de outro, não são igualmente livres, o que leva à divisão da liberdade. Tal é a tarefa do último capítulo da obra (226,3-18):

1. Uma liberdade que é por si ( $a s e$ ), que não foi criada.

2. A liberdade dos homens e dos anjos, que é dada por Deus (a Deo). Encontramos aqui uma dupla distinção entre aqueles que possuem a retidão e aqueles que carecem dela.

Para aqueles que possuem a retidão, Anselmo apresenta uma nova subdivisão, que em suas palavras é a seguinte:

a) separáveis (dela): os anjos antes da queda e os homens antes da morte;

b) inseparáveis (dela): os anjos e os homens eleitos.

Para aqueles que não possuem a retidão, o doutor Magnífico apresenta uma subdivisão, agora sob nova designação:

a) recuperáveis (que podem recuperá-la): os homens nesta vida;

b) irrecuperáveis (que não podem recuperá-la): os anjos réprobos após a queda e os homens réprobos após a morte.

Tal divisão apresenta, num primeiro momento, uma consideração de ordem metafísica que relembra os capítulos iniciais do Monologion (4,17:29-30): a afirmação de algo que é por si, e pela qual tudo o mais é (ratio docuerit id quod per se est et per quod alia cuncta sum"). Num segundo momento, e já mais próxima de um conteúdo moral, a indicação direta de uma liberdade criada, a qual comporta uma referência ao problema do pecado.

A noção de liberdade apresenta, como determinação própria, a retidão da vontade, que por sua vez não é outra coisa senão a expressão da justiça. Dessa forma, a liberdade em Anselmo está direcionada para a justiça.

\section{Conclusão}

É possível afirmar, a título de conclusão, que o horizonte filosófico do diálogo anselmiano é aquele de Santo Agostinho: a presença de uma vontade livre é o núcleo da discussão sobre a liberdade, em relação à qual recai todo o esforço do entendimento humano. Que Deus não seja o autor do mal e que o livre-arbítrio seja um bem, oferecido por Deus ao homem, os dois autores aqui analisados tomam como expressão da certeza da fé. O ponto de partida de Anselmo, aquele de pensar a liberdade como a reta determinação para o bem, expresso na sua definição como o 'poder de conservar a retidão 
da vontade pela própria retidão', implica que o livre-arbítrio, ausente qualquer tipo de coação, é livre para escolher o bem, sendo a liberdade algo essencial da criatura racional. No entanto, o doutor de Hipona não desconhece a idéia de uma primeira liberdade como 'poder de não pecar' (cf. De corruptione et gratia, XII,33), signo de uma libertas que se realiza na adesão ao bem. O ponto de partida de Anselmo para considerar a liberdade, como retidão da vontade, é o ponto de chegada de Agostinho, indicado pela vera libertas.

Quando Anselmo considera a vontade em sua determinação essencial, o foco da análise parece distanciar-se daquela de Agostinho. Para o bispo de Cantuária, a vontade é considerada como um instrumento do querer, como uma das faculdades do homem, sendo algo na alma e não toda a alma. A vontade é considerada sob uma tripla perspectiva: uma vontade-instrumento, uma pura vontade ainda não orientada para um fim determinado; a vontade-afecção, inclinada à felicidade ou à justiça; a vontade-ação, que é a realização efetiva do querer ${ }^{23}$. Aspecto novo nessa orientação de Anselmo é a determinação da justiça, que será o centro a partir do qual será possível falar da liberdade. Para Agostinho, o traço distintivo da vontade, em seu sentido mais abrangente, é a sua inclinação à felicidade, ou melhor, a de que todo homem tem a vontade de ser feliz. Na obra que escolhemos para orientar nossa reflexão nesse artigo, a prova oferecida a Evódio acerca da presença da vontade, é justamente o fato de que toda criatura racional quer ser feliz. Na tradição 'voluntarista' que os historiadores reconhecem na ética filosófica medieval, ao papel pioneiro de Agostinho, deve-se acrescentar aquele de Anselmo, cuja reflexão sobre a liberdade vem revelar toda a grandeza da criatura humana.

\section{Referências}

AGOSTINHO DE HIPONA. Diálogo sobre o livre-arbitrio. Lisboa: Imprensa Nacional Casa da Moeda, 2001.

. Il de libero arbítrio de Agostino. Studio introduttivo, testo, traduzione e commento Franco de Capitani. Milano: Vita e pensiero, 1994.

. Il libero arbitrio. Roma: Città Nuova Editrici,1992.

. Confissões. São Paulo: Cia das Letras, 2017.

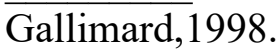

. Les Confessions. Dialogues philosophiques. Oeuvres I. Paris:

\footnotetext{
${ }^{23}$ Cf. Anselmo, De concordia, III, caps 11-13.
} 
. Diálogo sobre a ordem. Lisboa: Imprensa Nacional Casa da Moeda, 2000.

2008. . A Cidade de Deus. Lisboa: Fundação Calouste Gulbenkian,

ANSELMO DE CANTUÁRIA, Opera omnia. Stuttgart: Bad Cannsttat, 1984. . L'Oeuvre de S. Anselme de Cantorbery (vol. 1-8). Paris: Cerf,1986-2002.

BOÉCIO, Consolação da Filosofia. São Paulo: Martins Fontes, 1998.

EVANS, G. Anselm and talking about God. Oxford: Clarendon Press, 1978.

GILSON, E. L'Esprit de la philosophie médiévale. Paris: Vrin, 1969.

. L'Introduction à l'étude de saint Augustin. Paris: Vrin, 1987.

HADOT, P Marius Victorinus. Recherches sur sa vie et ses oeuvres. Paris: Études augustiniennes, 1954.

HOPKINS, J. A companion to the study of St. Anselm. Minneapolis; University of Minnesota Press, 1972.

PLATAO, A República. São Paulo: Martins Fontes, 2006.

RICOEUR, P. O mal. Um desadfio à filosofia e à teologia. Campinas: Papirus,1988.

VANNI-ROVIGHI, S. Etica in S. Anselmo. In: Analecta Anselmiana I. Frankfurt: Minerva, 1969. 